\title{
The concepts information and communication: perspectives from the academic communities of information, communication and computer engineering sciences
}

\author{
Martha Sabelli ${ }^{I}$ \\ https://orcid.org/0000-0002-4130-0312 \\ ${ }^{I}$ Universidad de la República, Montevidéu, Uruguay. \\ Profesora Titular Grado 5, Coordinadora del Departamento \\ Información y Sociedad del Instituto de Información de la Facultad \\ de Información y Comunicación (FIC) de la Universidad de la República.
}

http://dx.doi.org/10.1590/1981-5344/3360

We present an exploratory research that took place between 2013 - 2015, focusing on the perceptions regarding Information and Communication of fourteen PhD investigators, in two interdisciplinary centers in Brazil and Spain. This research is part of a new line of investigation initiated in 2014 by the Research Group: The concepts 'Information' and 'Communication' from the perspectives of several disciplines (Communication, Information Science and Computer Engineering) - CIC, in the Faculty of Information and Communication (FIC) of the University of the Republic, Uruguay. The dimensions of analysis defined to study the perceptions of the academicians are: academic formation, approaches to the Information and Communication concepts; similarities and differences between such concepts and theoretical references. The research strategy is based upon qualitative methods focused on in-depth interviews with qualified informants. Interviews were recorded in Spanish and Portuguese and transcribed into Spanish. A qualitative analysis was conducted by means of systematic techniques including content analysis of the discourse as well as reading and interpretation of the content which was presented in the corpus of the 
interviews. The perceptions of the academicians were categorized according to the disciplinary fields to which they belonged. General and specific conclusions about tendencies are presented, both supporting the need to promote reflection and debate in the interdisciplinary scientific community, focusing on the concepts of Information and Communication.

Keywords: Concepts; Information; Information science; Communication; Interdisciplinary academic communities.

\section{Os conceitos de informação e comunicação: perspectivas das comunidades acadêmicas de ciências da informação, comunicação e informática}

Apresentamos uma pesquisa exploratória que ocorreu entre os anos 2013-2015, focada nas percepções sobre Informação e Comunicação de 14 pesquisadores com doutorado, em dois centros interdisciplinares no Brasil e na Espanha. A pesquisa faz parte de uma nova linha de pesquisa iniciada em 2014 pelo Grupo de Pesquisa: Os conceitos de "Informação" e "Comunicação" das perspectivas de várias disciplinas (Comunicação, Ciência da Informação e Engenharia Informática - CIC. As dimensões de análise definidas pelo estudo das percepções dos acadêmicos são: formação acadêmica, abordagens sobre os conceitos de Informação e Comunicação, semelhanças e diferenças entre cada conceito $E$ as referências teóricas. A estratégia de pesquisa é baseada em métodos qualitativos focados em entrevistas em profundidade com informantes qualificados. As entrevistas foram registradas em espanhol e português e transcritas em espanhol. Uma análise qualitativa foi realizada através de técnicas sistemáticas, incluindo a análise de conteúdo do discurso e interpretação do conteúdo presente no corpus das entrevistas. As percepções dos acadêmicos são categorizadas de acordo com os campos disciplinares a que pertencem. As conclusões sobre tendências gerais e 
específicas baseiam-se na necessidade de promover a reflexão e o debate nas comunidades científicas

Palavras-chave: Conceitos; Informação; Ciência da Informação; Comunicação; Comunidades_acadêmicas interdisciplinares

\section{Los conceptos información y comunicación: perspectivas desde las comunidades académicas de las ciencias de la información, comunicación e ingeniería.}

Se presenta una investigación exploratoria que tuvo lugar entre los años 2013-2015, centrada en las percepciones sobre Información y Comunicación de 14 investigadores con PhD, en dos centros interdisciplinarios en Brasil y España. La investigación es parte de una nueva línea de investigación iniciada en 2014 por el Grupo de Investigación: Los conceptos 'Información' y 'Comunicación' desde la perspectivas de varias disciplinas (Comunicación, Ciencia de la Información y Ingeniería en Computación - CIC, en la Facultad de Información y Comunicación (FIC) de la Universidad de la República, Uruguay. Las dimensiones de análisis definidas por el estudio de las percepciones de los académicos son: formación académica, enfoques sobre los conceptos Información y Comunicación; similitudes y diferencias entre cada concepto y referentes teóricos. La estrategia de investigación se basa en métodos cualitativos centrados en entrevistas en profundidad a informantes calificados. Las entrevistas fueron grabadas en español y portugués y transcritas en español. Se realizó un análisis cualitativo a través de técnicas sistemáticas, incluyendo el análisis de contenido del discurso, así como la lectura e interpretación del contenido presente en el corpus de las entrevistas. Las percepciones de los académicos están categorizadas según los campos disciplinarios a los que pertenecen dichos académicos.Se presentan conclusiones sobre tendenciass generales y específicas, ambas fundamentan la necesidad de promover la reflexión y el debate en las comunidades científicas interdisciplinarias centradas en los conceptos Información y Comunicación. 
Palabras claves: Conceptos; Información; Ciencia de la información; Comunicación; Comunidades académicas interdisciplinarias

Recebido em 02.12.2017 Aceito em 27.02.2019

\section{Introduction}

The present research is part of a new line of investigation initiated in 2014 by the Research Group: The concepts 'Information' and 'Communication' from the perspectives of several disciplines (Communication, Information Science and Computer Engineering) - CIC, was carried out at the Faculty of Information and Communication (FIC) of the University of the Republic (Uruguay) - Udelar). The creation of the Faculty in October 2013 by the Udelar, coupled the former Library and Related Sciences School (EUBCA, 1943-2013) with the degree studies in Communication Sciences (LICCOM, 1986-2013). From December 4, 2013 they have worked as the Information Institute (Information Science-IS) and Communication Institute.

The emergence of the FIC was preceded by the foundational process of the Program for the Academic Development of Information and Communication- Prodic- which took place from 2009 to 2013, enabling the integration between the Information and Communication disciplines along with the creation of groups and interdisciplinary research projects, and also with the Master in Information and Communication. For a short time, Prodic was a productive and enriching project. Academicians of IS and Communication Science-CS began to share knowledge in a mutual context with linguists, sociologists, anthropologists, philosophers and computer engineers.

Such scenario also presented challenges regarding the difficulties and limitations faced by academicians from IS, IC and Computer Engineering when identifying similarities and differences related to the Information and Communication concepts.

The main questions that lead this research line are: what underlying notions are found in relation to the information disciplines' main actors with regard to these two key concepts? That is, related to the daily academic life and working environment, and not only to the academic corpus created by the most important theorists on the subject. On the other hand: what is the relation between the perspectives of the academicians and the corpus of the theoretical referents?

The CIC Group and its research line provide a background for the current presentation on the different perspectives of interdisciplinary academic experiences in Brazil and Spain, whose main objective is contributing to the research, reflection and debate on this topic in Uruguay (2016-2018). It is worth remarking the valuable contribution to the CIC's recent investigation by Lourdes Garcia Aguirre (2015) -MSc in 
Education and Professor of Philosophy- centred on a systematic bibliographic review of the Information concept in Latin America from the perspective of IS, through 39 articles and chapters in collective books belonging to 35 authors from Brazil, Colombia and Mexico published between 2010-2015. It is a completely original study we could witness as a tutor which has no precedents in Latin America and that was subject to strict scientific principles. Garcia Aguirre (2015, p 61-129) created six categories of analysis and content interpretation which allowed her to group the notions of the selected Latin American authors, as well as to develop a comparative analysis of the categories and social networks among them (p.130-148).

Consequently, another aim of our investigation is to present those studies which are currently taking place in Latin America to an international audience. Studies we believe isolated from the English academic world, where most of the information is disseminated either in English or in other languages through events or academic journals.

We will present an exploratory research that took place between 2013 - 2015, focusing on the perceptions on Information and Communication of fourteen $\mathrm{PhD}$ investigators, in two interdisciplinary centers: the Escola de Ciência da Informação da Universidade Federal de Minas Gerais (ECI-UFMG) in Brazil, and the PhD Program in Communication, Information and Technology of the Network Society CITYNET, University of Alcalá (UAH) in Spain.

Both cases offer an interdisciplinary approach to information disciplines, with the ECI focusing on the integration between Library and Information Science (LIS), Archival Science and Museology and their relation to Information Science (IS). In the CITYNET D430 PhD Program, a proposal based on Scientific Documentation, Audiovisual Communication and Computer Engineering is introduced as well.

Our academic stay in both universities from 2013 to 2015 allowed us to maintain a close contact with the respondents during the time of the interviews, all of them were conducted with academicians with PhDs in IS. Our research took place during such period, coinciding with our postdoctoral training at the University of Alcalá.

The specific objectives of the research are: a) analyzing the trends with reference to the perceptions of the academic community in the fields of the information and communication disciplines regarding to the concepts 'Information' and 'Communication'; b) identifying the main concepts and their similarities/differences among several disciplinary profiles (Information Science, Communication and Computer Engineering); c) understanding the relationships between the perceptions and the academic life context (training and experience) of the subjects objects of the investigation; and d) collecting data on their theoretical framework in order to triangulate the analysis with other sources of information in the research stages to follow (2016-2018), which will take place among the academic community at the FIC (Uruguay). 


\section{Reference framework}

To expose, or at least to mention, the main theoretical referents in the conceptualization we propose, implies an impossible challenge: to consider both the founders of IS during the the 60 s and 70 s -adhering to David Bawden's (2008) notion regarding "smoother pebbles and the shoulders of giants"- such as H. Borko. (1968), J. Farradane (1979), B.C. Brookes (1980), N. Belkin (1978) and G. Wersig and U. Nevelling (1975), while recognizing the "masters" who influenced the construction of the theory: M.J. Bates (1999), D. Bawden, D. (2007), M. K. Buckland (1991), B. Dervin (2005), P. Vakkari (1997) and B. Vickery (1997).

In short, the Information concept from IS, is fundamental for all its metatheories, as well as for those academicians who have opted for innovative socio-cognitive and social perspectives, enabling a further insight on the concept during the late 90 s and early 2000s. Thus, mention should be made to R. Capurro's Hermeneutics (1992, 2000), the information in organizations of C.W. Choo (2001), the "philosophy of information" of L. Floridi (2011), the intentionality of human action of J. M. Budd (2011), the "cybersemiotics" of S. Brier (1992) or the critical and dialectic approach of B. Frohmann (2004). Also, to B. Hjørland and $\mathrm{H}$. Albrechtsen's (1995) theory of Domain Analysis, or to B. Hjørland (1998, 2004, 2007) and Ørom's (2000) vision of the historical perspectives of IS.

Finally, it is worth noting the synthesis made by Ørom, as well as by Donald Case in Chapter 3 of his prestigious work "Looking for information" (2012, chapter 3), apart from the research carried out by David Bawden and Lyn Robinson (2012), in addition to Marcia Bates' revisions on metatheories and theories (2005, p.1-24). The similarities and differences among them enriched both the dialogue and the debate, which instead of becoming fragmented, helped generating opinions among those academicians and professionals dedicated to the information disciplines.

In this regard, the production collected within 25 years of CoLis Conferences, has proved to be the best scenario for these theoretical transformations. Each event has exposed vast conceptual advances, promoting a prolific dialogue among the supporters of the different concepts on the information phenomenon from a holistic, comprehensive and contextualized point of view being, at the same time, immersed into different perspectives and interpretative paradigms that share the common aim of strengthening the information disciplines theories. To illustrate it, we can take the role of Marcia Bates in CoLis 6 (Bates, 2007) -which provides an excellent description of information disciplines and of her vision of Information in the $21^{\text {st }}$ century- , or the clever and creative discussions in CoLis 7 regarding "unity in diversity" -particularly the panel sessions around the metaphorical figure of a snowman. All these are unforgettable instances where wisdom, scientific rigour and intellectual capacity emerged with creativity and humor. 
In Latin America, the development of theories focused either partially or completely on the Information concept from the Information Science theory, has been exhaustively mapped and categorized in Brazil, Colombia and Mexico -as we already mentioned- by García Aguirre (2015). Such research is shortly to be published in the books and academic journals to which we referred before. With regard to the referents of the analyzed authors (pp.137-138), the three most cited according to their origin are: Capurro (10), Hjørland (8) and Floridi (7) Europe-, Frohmann (7), Buckland (5) and Saracevic (4) -in an AngloSaxon setting (United States, Canada and England)-, and Rendon Rojas (8) -Latin America.

Our investigation concentrated on prestigious universities having research departments and which offer postgraduate courses. In most of them, we observed an integrated view of information. The leading one is the Institute of Library Research and Information - IIBI [Library and Information Research Institute] from the Autonomous University of Mexico - UNAM, whose books are available online: The leading one is the Institute of Library Research and Information - IIBI [Library and Information Research Institute] from the Autonomous University of Mexico - UNAM, whose books are available online.

At the IIBI, Miguel Ángel Rendón Rojas -a researcher with a PhD in Philosophy- specializes in metatheoretical studies of Library and Information Science, which he named Library Science / Documentation / Information Science, taking into account the different denominations used in Latin America and Spain. His vast academic production is widely known, and he organizes and coordinates the main Latin American Seminar on the theory of information disciplines at the IIBI, presented in books (Rendón Rojas, 2014a, 2014b, 2013) as well as in Library Science journals. He has investigated the epistemological concerns of the 'documentary informative phenomena' and his research focuses on the epistemological and theoretical analysis of both library science and information studies -unity in the diversity: library science and information science documentation. Three papers on the concepts of these disciplines (Rendón Rojas 1995, 2005a, 2005b) excel. There, he centers in the cognitive approach and the social paradigm.

We perceive a substantial background in Brazil, essentially influenced by the French theorists -Le Coadic (2004). As a leader in the theoretical construction of the integration of disciplines, which is presented in his original and prolific production, we would like to mention the works of Carlos Alberto Araújo Ávila, and to refer to his academic career characterized by his papers regarding the concept of information (Araújo 2010, 2014) based on a semiotic component, and adhering to the socio-cognitive and social perspectives.

Finally, due to its consistency with the objectives of our new line of research and our concern about interdisciplinarity between Information and Communication concepts, we would like to mention the recent paper: 'O debate retomado: conflitos e convergencias entre comunicacao e 
informacao' by Weber and Stumpf (2015), where three dimensions of interdisciplinarity between Communication and Information are identified: dependence, mediation and intervention.

\section{Methods}

The dimensions of analysis defined to study the perceptions of the academicians are: academic training, approaches to the Information and Communication concepts; similarities and differences between such concepts, and theoretical referents. The questions they were asked were: How was your process of academic training (graduation, Master studies, $\mathrm{PhD}$ ) and how did topics related to information and communication appear ?; Which are your approaches to the Information and Communication terms ?; Could you mention some writers, thinkers and theorists of your choice?; Could you identify common areas between Information and Communication? What about the differences? Such questions worked as a semi-structured script, since they are open questions which seek to encourage the dialogue. Thus, quoting Yin: "(if the interviewer) follow(s) a conversational mode ... the interview itself will lead to a social relationship of sort" (Yin, 2015, p.142). Thus, we intended to understand and interpret the perceptions of the subjects - objects with reference to the studied phenomenon. As Patton points out : "The purpose of interviewing is to find out what is in and on someone else's mind [...] is to allow us to enter into the other person's perspective. Qualitative interviewing begins with the assumption that the perspective of others is meaningful, knowable, and able to be made explicit" (Patton, 1990, p.278). During the interviews, the researcher adapted the interview guide to the pace and content of the answers, aiming to obtain the respondents' points of view in the most accurate and flexible way. We prioritized the respondent's central role, while the interviewer mainly focused on listening actively, observing, taking notes and encouraging the emergence of new contributions from the respondent (expressed in his/her own words) by using an appropriate strategy based on mutual trust and spontaneity.

Therefore, the research strategy is based upon qualitative methods focused on in-depth interviews with qualified informants, centered on the four aforementioned dimensions. The 14 respondents were selected among researchers of the ECI and the D430, taking into account their participation in doctoral programs, the interdisciplinary present in both their undergraduate and graduate courses, but also their high qualifications as researchers. It is a purposive sample that intended to select those respondents who could contribute with relevant information.

Interviews were conducted by the author, mostly at the respondents' workplaces (offices in universities), except in three cases, which were carried out in sites of the university campus chosen by the respondents themselves. Interviews lasted between 45 and 60 minutes and were characterized by their relaxed atmosphere, where the interviewer was considered an equal who could be trusted. It was our 
intention to achieve a fluent and spontaneous dialogue without introducing preliminary data regarding the content of the interview to be made, attempting to foster the emergence of personal perceptions in a type of narrative which differed from the academic production of respondents in publications or other media. When the respondents 'speech deviated from the purpose of the interview, the interviewer asked specific questions to re-focus the dialogue on the dimensions and objectives of the research -as it is common in qualitative methodologies that use phenomenological approaches.

Interviews were recorded and transcribed in Spanish while those corresponding to Portuguese texts were translated into Spanish. Transcripts were rigorously revised in order to include the exact expressions used by the respondents. They were also checked by the author, who heard the audio several times to identify the differences in rhythm, silences and tones.

A qualitative analysis was conducted by means of systematic techniques including content analysis of the discourse, as well as reading and interpreting- the content (manifest and latent) present in the corpus of the interviews.

\section{Analysis of results}

The analysis of the interviews reflecting the perceptions of the academicians is categorized according to the disciplinary fields to which such academicians belong to - Information Science (IS, in Spain: Documentation Sciences-DS), Communication Science and Computer Science- in order to examine their conceptualizations by comparing them according to the four analytical dimensions determined in the methodology.

\section{Process of graduate and post-graduate academic formation and emergence of the subjects 'Information' and 'Communication'}

The ten academicians -professors and researchers- in the areas of IS / DS offer a diverse background as a result of having graduate and post-graduate formation in different disciplinary fields. Both interdisciplinarity and multidisciplinarity are present in their academic lives and private practices. Four of the respondents obtained the degree in Library and Information Science (LIS). The rest of them have graduate studies in Political Science, Computer Science, Philosophy, History and Medicine, as well as in Secondary Education (Mathematics and Physics) and school teaching. Nonetheless, the Master post-grades (1), and especially the PhDs are related to LIS (7), although there PhDs in Philology(1) and Museology (1). It is worth highlighting that 
Master studies became relatively recent in Spain, and that most of the Spanish respondents graduated during the decades of 1980 and 1990.

Subsequent graduation performance in centers and services related to documentation or information (R1), databases management in hospitals (R6), the Ministry of Justice, scientific research organizations or cultural societies (R2), encouraged the academicians' interest in specializing in postgraduate courses in LIS.

Both R10 and R13 express rejection towards the professional practice in Computer Studies, along with their discovery of IS and the subsequent option of PhDs studies that included thesis subjects associated to their interests.

The two interviewees who belong to the field of Communication (specifically Audiovisual Communication) have training degrees in Philosophy and Psychology (R3), as well as in psycho-pedagogy (R5); both having finished their PhDs in the latter area. Their research studies focus on the audiovisual area, specifically on video games.

Regarding the two respondents -R2 and R7- from the field of Computing Studies, they both obtained-degrees and PhDs in Computer Engineering, although they characterize by researching and working on topics related to ontologies and the semantic web. Therefore, they are closely linked to DS courses. One of them graduated in this discipline after a PhD in order to better understand the thesauri, as well as the organization of knowledge in general.

Two respondents excel due to their important interdisciplinary training (R3 and R11), with several graduations and postgraduate courses which will later be revealed in the analysis.

In summary, the academic profile of the respondents enables us to identify and interpret their perceptions from interdisciplinary areas separated from their contexts and their academic background.

Perspective of the concepts of Information and Communication from the Information Science academicians

Several respondents associate the Information concept to the different currents within IS through the XX century, differentiating between those which were more related to technology from those presenting a more human and social vision, as visibly indicated by R1:

Information as an object of study in our discipline [...] was the result of the convergence of various disciplines, the Mathematics, the technological deployment, the essence of the ancient theory of Documentation, and also the sociological and 
social perspective in the last third or second half of the $X X$ century that has defined two perspectives regarding how to approach research: the 'machine' one, which relates to technology and product development, and that is also at the front of the information retrieval (IR ), and then the perspective, the other front, we may call 'human'...

The recognition of information as a process -as distinct from the reductionist view of information/object- and its close relation to knowledge is defended in general both from Brazilian and Spanish respondents:

I prefer to consider Information more as a process than as an object, the process of 'shaping'. I separate information from the concept of document, of data. It is a process related to the interpretation, the package of interpretation plus meaning.

[...] our subject matter has to do with information as a synonym of knowledge, information as a generator of knowledge and in turn, of knowledge as a generator of information ... (R1).

However, we have also spotted other perceptions located at the very origins of LIS. On one hand, R9, concerned about the essence of LIS, about conserving and preserving information for the future. On the other hand, R14 is closely attached to the management of information systems and the IR, who, even from a more social perspective also refers to these functions.

An aspect which is typical of the information is its presentation and conservation [...] we librarians have a role, the question of selecting, storing and preparing for future generations.(R9).

I give importance to quality, to the access to information, to know how to manage, organize or disseminate it [...] this justifies the sub-disciplines of the DS (R4).

Among Brazilian academicians a significant French influence is observed, which becomes evident in the role assigned to linguistics:

... we are thinking about an information system that is a system for the communication of information; the main category for us to work with information is the language category (R12).

The two respondents related to Archival Science (R8) and Museology (R11), present a comprehensive view about IS, and express an enriching positioning regarding this discipline and its interdisciplinary relations. Information is acknowledged as part of their interdisciplinary training (History, Philosophy, Librarian-Archivist, IS) related to the post-custodial paradigm to which they adhere, considering that this not only contains 
theories, but also values, attitudes, axiology. Information is related to explicit knowledge, whereas implicit knowledge is related to cognition. Information is defined as 'a structured collection of mental representations, coded emotions (signs or symbols) shaped by social interaction, transformed into a language which is a social tool that you introduce in your brain'. In sum, this concept incorporates both the psychic and the social in a paradigm named as 'post-custodial, informational and scientific'. (R8)

From Museology -which R11 discovered after a starting with the teaching of Physics- due to his/her interest in 'subjects who should understand the scientific language' to see what is necessary for 'people to understand what policies lay behind it'.

Finally, from IS field, the impact of technology becomes notorious in the concepts of document and information. They consider the development of hypertext systems -that ended up fragmenting the idea of document and promoting the process of disintegration of the sequential structure that was characteristic of printed documentation- as a precedent. The dynamism of the electronic document implies that 'documents do not exist until someone "calls" them, they are distributed within the network and become integrated when they are 'called' upon', the idea of a replica is replicable and easy to manipulate, and has an effect on certain fundamentals which have supported it, such as the authenticity'. (R1)

The Communication concept is related with much of the discourse in the media and with the transformation of society and culture. In some cases, we observe a specific connection with journalism. In Spain, Communication Science studies are located in faculties or university departments under the name of Information Sciences. Such respondents emphasize the importance of accessibility, information retrieval and research on IS. In this regard, they state:

'... communication theories appear as a consequence of the emergence of social communication media, the transformation of the concept of culture, of society, of mass society [...] They are different, since the object of study does not refer to information, or to how to make it accessible or retrievable. It is an idea related to the social communication media'. (R1)

'... in Spain this idea is understood as linked to journalism it is the ability to understand messages. The issue of communication is closely connected to good communication with a scientific basis. (R4).

Others present a more comprehensive approach to the concept, focusing on the action of communicating and on its relation to inform, an indivisible binomial:

'Communication theory has to do with communicating something to someone; I have to know how want to communicate to, in order to know how I will communicate' (R10). 
'Communication is the extension of information that already exists, which must be located and transmitted or transmitted and located, so that at some point it returns to be part of knowledge. Those are two indivisible concepts. There is no information if there is no communication and no communication if there is nothing to report' (R6).

From the point of view of Museology the close relation between communication and information can be observed in the context of museum exhibitions:

'For communication to exist, information is necessary, I do not see them as separated [...] facts alone do not mean anything. [...] When we deal with museum management, communication is much more "spacious", having information does not assure that there was communication, because there is no interaction between those subjects who are to communicate and rebuild speeches based on the information they own. I have a broader view of communication. [...] When we work in Museology, communication occurs through exhibitions, information is present there, visitors, users, the public, will communicate in that setting, in that context' (R11).

Despite the claim of R14, there is a discourse where IS and Communication become very close. The respondent states:

'Communication means 'public relations', journalism, 'advertising', nonverbal communication, very different subjects from IS issues. There are very different concerns; research topics are very different from those of the IS. What would be closer to the IS would be the areas of dissemination, transmission of information...

R12 addresses the relation information-communication from a holistic perspective centered on the role of language and on the examination of the document as documentary instruments in the mediation of information. In this regard, R12declares:

'My whole comprehension concerning information was underpinned by the linguistic element, how I operate with it, all the methodologies and tools needed for representation. (They) go through that understanding of what language is. The text perceived as language, as a linguistic expression. (They) need to respond to the communication process, leading to an appropriation of the information by the subject, communication being the target of the process we work in, and information as the element with which we are working" (R12). 
In summary, information is conceived as a dynamic process related to knowledge, existing in a technological setting whose impacts imply changes in the concept of information saved in printed documents. Destructuring appears with the emergence of digital documentation. Communication is understood by a sector as social communication, specifically journalism. Yet, a major number of respondents identified significant contributions of the theories of Communication to IS and they refer to the existence of an indivisible binomial: Information \& Communication.

\section{Perspective of the concepts Information and Communication from academicians in Audiovisual Communication}

From a noticeably interdisciplinary training, R3 addresses concepts from a holistic and innovative point of view, with a strong influence of the new Big Data approaches. Accordingly, the respondent argues that Communication 'implies reconstructing knowledge somehow' as it is focused on 'a process which includes a sender, a receiver, and a mediator, and communication is interpreted, for communication to exist it is necessary that someone is interpreting it ...' R3 strongly identifies the existing differences with Information from a LIS perspective, 'information is generated, organized and classified by you. I suppose that a librarian may be thinking of a receiver who is not part of an audience, but more like part of a classification'.

As we will observe when dealing with the dimension of the thinkers, their preferences are directed to three theoreticians: Barbara Rogoff, Michael Cole and Henry Jenkins. They insist on placing communication in a socio-cultural line influenced both by ethnography and anthropology. Their concepts are oriented towards digital ethnography without neglecting the information theories, especially the metadata. Information is 'a wide abstract concept, from the content itself to what it conveys'. Communication is perceived as '...the various channels we own to convey information, or create it, to tell and share both content and form. Communication is a form, the language, the means, the channel. It is the key that enables people to create contents'. (R5). This respondent takes several visions into account: a "purest" communication related to the media and a more social communication, 'which is occurring promoted by the social changes we are living through, such as social networks, blogs, interactive newspapers, radio, digital TV'. Proximity between these two lies in the people, the individuals, the audience, "this is the key, the most important element". Other elements are the channels and the language, which transmits ideas. When referring to the aspects that separate them, the respondent hesitates, but then states:

Communication is the stage of transmitting information, such as a term I can find on a page or in different devices, and communication is how to transmit this, how to capture it, how 
the relation or connection between people or animals is developed; what we understand as sender and receiver. The message is part of this information.

Nonetheless, R5 prefers to differentiate between 'Information and Knowledge - Information is what we own; knowledge is what gives us such power, to understand that information, to be critical and reflective with it'.

Summarizing, amongst specialists in Audiovisual Communication, it is predominant the concept of Communication as a channel of information, facilitating its creation and sharing from a socio-cultural perspective, where the existence of people is essential to interpret it.

\section{Perspective of the concepts Information and Communication from academicians in Computer Engineering (Computer Studies)}

As it was obvious and expected, the two engineers ( $R 2$ y $R$ 7) perceive Information as part of their discipline, i.e., transmission of data via computers. They express their concern over the treatment given to information in order to transmit it efficiently, as well as to 'solve various problems in the relation between men and machines" and point out: 'to make it possible that the user, who is on the other end, communicates with the computer, there are many areas of knowledge to be studied'.

We also found consensus in the discourses related to their training as computer engineers: 'information appears as a representation of databases, data structure, in a very basic level without analyzing much the information per se, how to deal with it, store it, or recover it'

Conversely, R2 y R7's claim information is significant and also unpredictable. They mention an important influence of the DS: '... as for DS, it's another approach, information relates directly to how it is communicated and all subjects somehow refer to information'. R7 states 'I know that for classical theories and definitions, information is not only the data itself but the act of communicating it, or of producing such information to inform' (R7). Meanwhile, R2 addresses the concept of Information from his/her $\mathrm{PhD}$ thesis in Computer Engineering about ontology.

With regard to the dimensions Communication and Relation between Information and Communication, the two respondents regard as essential the presence of communication in the transmission of information: 'Communication conveys information, in the widest sense of the word, including feelings or experiences. The communication without the mediation of an electronic device conveys information. (R2).

We found interesting the treatment given to Communication by the two disciplines on which it is based, emphasizing the place it has for IS, in contradistinction to its place in the field of Computer Science: 'In Computer Science, communication was not a concern; but in DS its concept is debated. Various subjects deal with such concept and different 
theories of Communication are studied.'(R7). Also, perceiving communication as a process / actions aimed at individuals or groups of people:

'Communication does not communicate anything if there is no information; information by its mere existence has no value if it does not communicate. From that perspective there is an interrelation and a mutual need to exist together'. (R7)

Briefly stated, the two computer engineers -immerse in a context of an interdisciplinary PhD- appreciate the contributions of DS to their researches on the semantic network, specifically on ontology. Information and communication are conceptualized from this perspective; adhering to the binomial Information and Communication.

\section{Preferred theoretical references and authors}

The authors, thinkers and theoretical references preferred by the respondents are presented in the following table, where they are included according to the areas of knowledge within which they perform at university, as well as to the disciplinary fields to which the referents belong to. In line with the analysis of the dimensions mentioned above, respondents selected the referents that have mostly attracted their interest during their studies. They did it spontaneously and without preparation, except for R7, who supplemented data after the interview by mailing a list of authors.

\begin{tabular}{|c|c|c|c|}
\hline & $\begin{array}{l}\text { Information Science - } \\
\text { Documentation Science }\end{array}$ & $\begin{array}{l}\text { Communication } \\
\text { Science, Linguistics, } \\
\text { Psychology, Social } \\
\text { Sciences. }\end{array}$ & $\begin{array}{l}\text { Computer } \\
\text { Science }\end{array}$ \\
\hline $\mathrm{R} 1$ & $\begin{array}{l}\text { Cognitive specialists and hyper text } \\
\text { V. Bush. } \\
\text { Researchers in electronic } \\
\text { documents }\end{array}$ & & \\
\hline $\mathrm{R} 4$ & Influence of Anglo-Nordic theorists. & & \\
\hline R6 & $\begin{array}{l}\text { H.F. Moed, W.Glänzel, } \\
\text { L. Leydesdorff, J. Irvine, B.R.A } \\
\text { Martin, I. Gómez Caridad, F. Moya- } \\
\text { Anegón, B. Vargas Quesada, M. } \\
\text { Bondons }\end{array}$ & & \\
\hline R8 & $\begin{array}{l}\text { Le Coadic, H. Borko, } \\
\text { P. Vakkari, F.Capurro, A. García } \\
\text { Moreiro, M. A. Rendón Rojas }\end{array}$ & & \\
\hline R9 & T. Saracevic, , C T. Meadows, & $\begin{array}{l}\text { M. Castells, A. } \\
\text { Mattelart } \\
\text { P. Lévy, A. Lemos }\end{array}$ & \\
\hline $\begin{array}{l}\mathrm{R} 1 \\
0\end{array}$ & R. Capurro & $\begin{array}{l}\text { P. Charaudau, R. } \\
\text { Ghiglione }\end{array}$ & \\
\hline $\begin{array}{l}\mathrm{R} 1 \\
1\end{array}$ & & $\begin{array}{l}\text { T. Davenport, C. } \\
\text { Guimãraes, J. } \\
\text { Davallon, F. Chieli, }\end{array}$ & \\
\hline
\end{tabular}




\begin{tabular}{|c|c|c|c|}
\hline & & $\begin{array}{l}\text { D. Pignatari, A. } \\
\text { Parente, Y. Bergeron }\end{array}$ & \\
\hline $\begin{array}{l}\mathrm{R} 1 \\
2\end{array}$ & $\begin{array}{l}\text { P. Otlet, S. Brier, M.Desantes, } \\
\text { J. López Yespes }\end{array}$ & $\begin{array}{l}\text { B. Gardin, Temma } \\
\text { Group: M. Lara, F. } \\
\text { Tálamo, N. Kobascki, } \\
\text { A.M. Cintra, R. Obata }\end{array}$ & \\
\hline $\begin{array}{l}\mathrm{R} 1 \\
3\end{array}$ & F. Dretske, , L. Floridi & & C. Fox \\
\hline $\begin{array}{l}\mathrm{R} 1 \\
4\end{array}$ & $\begin{array}{l}\text { M. K. Buckland, B. Hjørland, B. } \\
\text { Dervin \& M. Nilan }\end{array}$ & & C. E. Shannon \\
\hline R3 & & $\begin{array}{l}\text { B. Rogoff, M. Cole, } \\
\text { H. Jenkins, J.Lave, H. } \\
\text { Levy, D. Tannen }\end{array}$ & L. Manovich, \\
\hline $\mathrm{R} 5$ & & $\begin{array}{l}\text { H. Jenkins, J. Adell, } \\
\text { D.Buckingham, C. } \\
\text { Scolari }\end{array}$ & L.Manovich \\
\hline $\mathrm{R} 2$ & & & J. Nielsen et al \\
\hline R7 & & & $\begin{array}{l}\text { J. Nielsen, } \\
\text { N. Guarino, T. } \\
\text { Gruber, T. } \\
\text { Berners Lee, T. } \\
\text { Heath, C. Bizer, } \\
\text { E. Duval, } \\
\text { D. Wiley, D. } \\
\text { Fensel }\end{array}$ \\
\hline
\end{tabular}

Table: The authors, thinkers and theoretical references preferred by the respondents.

Consistent with the analysis of other dimensions, respondents show uniformity in the concepts of Information and Communication, as in selecting their referents. Specificities were observed according to the areas of research and teaching, yet there is a predominance of major philosophers, specialists in linguistics and referents related to the theory of communication, in the selection made by the three disciplines.

\section{Conclusions and perspectives}

\subsection{Conclusions}

According to the results obtained from data collected during the interviews with those respondents related to Information Science, Communication Science and Computer Engineering, the Information and Communication concepts -as well as the theoretical referents on the topicpresent the following general aspects:

technological impacts with regard to the restructuring of the ways and the interactions imply changes in these concepts;

ontology technology and the Semantic Web have become central fields for Computer Engineers respondents, who appreciate the 
contributions of Information Science to their researches on the semantic network ;

the importance of linguistics, discourse analysis and, specifically, the voice of the documents i.e. the instruments to represent and interpret users -either as public or audience- are shared by the three disciplines respondents;

both concepts are perceived in a dynamic interaction with the social context;

the selection of referents is consistent with the discourse on the concepts and is characterized by the absence of many theoreticians mentioned in the referential framework. are detected:

Yet, some specific tendencies which justify to be later investigated

a relevant theoretical-methodological approach of researchers to their specialized fields of action, and certain separation from some of the paradigms or perspectives regarding the mentioned concepts or their literature;

influence of both academic and professionals experiences in the processes of conceptualization, the more the interdisciplinary, the richer the discourse content on the relation between the two concepts;

diversity in the degree of coordination among those researchers who are physically close at the University.

All these findings result in great help when developing the process of answering the main questions related to this line of research and the perspectives that follow:

\subsection{Perspectives}

The research results allow us to study the conceptualization of both Information and Communication in the new scenario of the Faculty of Information and Communication -University of the Republic- by using the methodology and the qualitative techniques applied at the University of Alcalá (Spain) and at the UFMG (Brazil). Apart from that, they help us to compare the similarities and differences in the perceptions of researchers from different disciplinary fields. Thus, we intend to be able to consolidate a line of research which contributes to the theory of Information Science in Latin America, based on the studies of different perceptions - in the context of everyday academic life - regarding the concepts Information and Communication in those interdisciplinary academic communities that belong to the information disciplines.

In this sense, our perspective at the CIC Group during the period 2016-2018, aims at developing an investigation about the perception, reflection and discussion on the concepts emerged in the FIC, using the technique of group interviews and focus groups composed by teachers and 
tutors in graduate courses. Therefore, the main objectives of this stage will be: a) to compare the results collected in Uruguay with the ones already presented here; b) to relate the concepts' properties and dimensions with the categorizations identified in the systematic review of bibliography presented by Garcia Aguirre (2015); c) to establish a connection with the production on the same subject by some Latin American theorists (i.e. Rendón Rojas, Araujo ...). It will also intend to promote- from the CIC Group- a systematic review of the Communication concept in Latin American journals, with the team of researchers in the field of Communication Science using García Aguirre's (2015) methodology. Finally, we will try to foster the construction by researchers of a sub-line of investigation in communication science, as a way to nurture comparative studies on this topic

Results will be made public at events and in journals. We look forward to presenting the first point (a) for discussion at CoLis10 as well as to receiving the comments and criticisms that will certainly enrich the investigation in our small Latin American country, where an interesting and original experience of interdisciplinary relations in the information disciplines is taking place.

\section{Acknowledgements}

The author would like to thank the research participants for their willingness to become part of the study, sharing their perceptions. She would like to extend her special thanks to Dra. Purificación Moscoso Castro from Universidad de Alcalá, (Spain), to Dr. Carlos Ávila Araujo from the Escola de Ciência da Informação da Universidade Federal de Minas Gerais (Brasil) for their constant advice and support and to her colleague Andrea Cristiani for the help in reviewing the writing style of this paper.

\section{References}

ARAÚJO, C.A. A. O conceito de informação na Ciência da Informação. Informação \& Sociedade: Estudos v.20, n.3, p. 95-105, 2010.

ARAÚJO, C.A.A. O que é Ciência da Informação?_Informação \& Informação, v.19, n.1, p.1-30, 2014

BATES, M.J. The invisible substrate of information science. Journal of the American Society for Information Science, v.50, n. 12, p.1043-1050, 1999.

BATES, M.J. An introduction to metatheories, theories and models. In: FISHER, K.E.; ERDELEZ, S.; MCKECHNIE, E.F. (Eds.). Theories of information behavior. Medford NJ: Information Today, 2005, p.1-24.

BATES, M.J. Defining the information disciplines in encyclopedia development. Information Research, v.12, n.4, 2007, paper colis29, Available at: http://information.net/ir/12-4/colis29.html. 
BAWDEN, D. Organised complexity, meaning and understanding: an approach to a unified view of information science. Aslib Proceedings, v.59, n.4/5, p.307-327, 2007.

BAWDEN, D. Smoother pebbles and the shoulders of giants: the developing foundations of information science, Journal of Information Science, v.34, n.4, p.415-426, 2008.

BAWDEN, D.; ROBINSON, L. Introduction to Information Science. Chicago, IL: Neal-Schuman, 2012.

BELKIN, N. Information concepts for information science. Journal of Documentation, v.34, n.1, p.55- 85, 1978.

BORKO, $\mathrm{H}$. Information science: what is it? American Documentation, v.19, n.1, p.3-5, 1968.

BRIER, S. Information and consciousness. A critique of the mechanistic concept of information. Cybernetics and Human Knowing, v.1, n.2-3, p.71-94, 1992.

BROOKES, B.C. The foundations of information science. Part 1: philosophical aspects. Journal of Information Science, v.2, n.3/4, p.12513, 1980.

BUCKLAND, M. K.. Information as thing. Journal of the American Society for Information Science, v.42, n.5, p.351-360, 1991.

BUDD, J. M. Meaning, truth and information: prolegomena to a theory. Journal of Documentation, v.67, n.1, p.56-74, 2011.

CAPURRO, R. What is information science for? A philosophical reflection. In : VAKKARI, P.; CRONIN, B. (Eds.): Conceptions of Library and Information Science. Historical, empirical and theoretical perspectives. London: Taylor Graham, 1992. p. 82-96. Available at: http:// www.capurro.de/tampere91.htm.

CAPURRO, R. Hermeneutics and the Phenomenon of Information. In: MITCHAM, C. (Ed.): Metaphysics, Epistemology and Technology. Research in Philosophy and Technology. New York: Elsevier. p. 79-85, 2000.

CASE, D.O. Looking for information: a survey of research on information seeking, needs, and behavior. 3rd ed.. Bingley, UK: Emerald, 1992.

$\mathrm{CHOO}, \mathrm{C} . \mathrm{W}$. Information managment for the intelligent organization: the art of scanning the environment. Medford, NJ: Information Today, 2002.

DERVIN, B. What methodology does to theory: Sense making methodology as exemplar. In: FISHER, K.E. ; ERDELEZ, S.; MCKECHNIE, E.F. (Eds.), Theories of information behavior. Medford NJ: Information Today, 2005.p.25-30.

FARRADANE, J. The nature of information. Journal of information science, v.1, n.1, p.13-17, 1979.

FLORIDI, L. What is the philosophy of information. Metaphilosophy, v.33, n.12, p.123-145, 2002. 
FROHMANN, B. Deflating information: from science studies to documentation. Toronto: University of Toronto Press, 2004.

GARCÍA AGUIRRE, L. El concepto de información en América Latina desde la ciencia de la información: revisión sistemática de literatura en Brasil, Colombia y México (2010-2015). Montevideo: Facultad de Información y Comunicación. Unpublished dissertation, 2015.

HJøLAND, B. Theory and metatheory of information science a new interpretation. Journal of Documentation, v.54, n.5, p.606-621, 1998.

HJØLAND, B. Domain analysis: a social-cognitive orientation for information science research. Bulletin of American Society for Information Science, v.30, n.3, p.1-11, 2004.

HJØLAND, B. Information: objective or subjective/situational? Journal of the American Society for Information Science and Technology, v.58, n.10, p.1448-1456, 2007.

HJøLAND, B. ; ALBRECHTSEN, H. Toward a new horizon in information science: domain-analysis. Journal of the American Society for Information Science, v.46, n.6, p.400-425, 1995.

LE COADIC, Y. A ciência da informação. Brasília: Briquet de Lemos, 1996 ØROM, A. Information science, historical changes and social aspects: a Nordic outlook. Journal of Documentation, v.56, n.1, p.12-26, 2000.

PATTON, M. Q. Qualitative evaluation and research methods. SAGE, 1990

RENDÓN ROJAS, M.A. La información como ente objetivizado. Investigaciones Bibliotecólogicas, v.9, n.18, p.17-24, 1995.

RENDÓN ROJAS, M.A. Relación entre los conceptos: información, conocimiento y valor. Semejanzas y diferencias, Ciência da Informação, v.34, n.2, p.52-61, 2005a.

RENDÓN ROJAS, M.A . Bases teóricas y filosóficas de la bibliotecología. México: UNAM, CUIB, 2005b.

RENDÓN ROJAS, M.A. (Ed.). El objeto de estudio de la bibliotecología / documentación / ciencia de la información: propuestas, discusión, análisis y elementos comunes. México: UNAM, IIBI, 2013.

RENDÓN ROJAS, M.A. El problema del lenguaje en la bibliotecología/ciencia de Información / documentación. Un acercamiento filosófico-teórico. México: UNAM, IIBI, $2014 \mathrm{a}$.

RENDÓN ROJAS, M.A. El ser, conocer y hacer en bibliotecología/ciencia de la información. México: UNAM, IIBI, 2014b.

VAKKARI, P. Information seeking in context: a challenging metatheory. In: VAKKARI, P.; SAVOLAINEN, R.; DERVIN, B. (Eds.), Information seeking in context: Proceedings of a meeting in Finland 14-16 August 1996. London: Taylor Graham, p.451-463, 1997. 
VICKERY, B. Metatheory and information science. Journal of Documentation, v.53, p.457-476, 1997.

WEBER, M.H.; STUMPF,I. R. O debate retomado: conflitos e convergencias entre comunição e Informação. Intexto, v.34, p.11-27, 2015.

WERSIG, G.; NEVELLING, U. The phenomena of interest to information science.

Information Scientist, v. 9, n.4, p.127-140, 1975.

YIN, R. K. Qualitative research from start to finish. Guilford Publications, 2015. 